\title{
In vitro co-culture system for Prunus spp. and Armillaria mellea in phenolic foam rooting matric
}

\author{
Jeffrey Adelberg ${ }^{1}$ (D) Jacqueline Naylor-Adelberg ${ }^{1} \cdot$ Sarah Miller $^{1} \cdot$ Ksenija Gasic $^{1} \cdot$ Guido Schnabel $^{1}$. \\ Patricia Bryson ${ }^{1}$. Christopher Saski ${ }^{1}$. Stephen Parris ${ }^{1} \cdot$ Gregory Reighard $^{1}$
}

Received: 4 September 2020 / Accepted: 3 November 2020 / Published online: 6 January 2021 / Editor: Randall Niedz

(C) The Author(s) 2021

\begin{abstract}
Armillaria and Desarmillaria spp. are causal agents of a devastating root-borne disease of peach. Breeding resistant rootstock requires a reliable screening tool. An in vitro co-culture screen designed for almond was modified by replacing agar-gelled medium with a more aerated phenolic foam and combining resistant and susceptible rootstocks (i.e., common garden experiment) and minimizes variation in inoculum pressure or rooting substrate among replicate vessels. Eight Prunus rootstocks tested (peach, plum, peach $\times$ plum, and choke cherry) were rooted and had no decline in health. Susceptible peach rootstock, 'GF 305', was cultured for $15 \mathrm{wk}$ in phenolic foam in the same vessel with a resistant peach $\times$ plum hybrid, 'MP-29', inoculated with Armillaria mellea at week 5, that led to more severe shoot symptoms in the former after an additional $8 \mathrm{wk}$. This method accommodated peach genotypes that were difficult to root in agar medium. The difference during a uniform challenge with the A. mellea fungus recapitulates resistant/susceptible reactions. The phenolic foam-based co-culture method will work on many Prunus spp. of potential use in rootstock breeding.
\end{abstract}

Keywords Disease resistance $\cdot$ Peach $\cdot$ Plum $\cdot$ Cherry $\cdot$ Oak root rot $\cdot$ Rootstock screening

\section{Introduction}

Armillaria root rot (ARR) is currently the greatest threat to peach production in the southeastern USA, with devastating impacts on cherries in Michigan, and sporadic occurrences on peaches and almond in California. Similar problems afflict orchards in China, Europe, the UK, and Mexico. The causal fungi are Desarmillaria tabescens (Scop.) R. A. Koch \& Aime comb. nov (Koch et al. 2017) and multiple Armillaria species including A. mellea (Vahl.:Fries) Kummer (Wilbur et al. 1972), A. mexicana R. Elías, Medel, Alvarado, Hanna, Ross-Davis, Kim, \& Klopfenstein sp. nov. (Elías-Román et al. 2018) and A. solidipes Peck (Devkota and Hammerschmidt

Key Message

Diverse germplasm of Prunus spp. was screened in vitro for resistance to Armillaria root rot with this robust assay. Aerated foam matrix allows better root morphology than agar.

Jeffrey Adelberg

jadlbrg@clemson.edu

1 Department of Plant and Environmental Sciences, Clemson University, Clemson, SC 29634, USA
2019). They are root-borne rather than soil-borne pathogens because they survive as saprophytes for many years in decomposing root matter buried deep in the orchard's soil. With the exception of a cultural method that delays the onset of the disease in peach orchards by about $2 \mathrm{yr}$ (Miller et al. 2020), there are no effective biological or chemical management options. New rootstocks with genetic resistance are urgently needed.

Most of the rootstocks for peach that were developed for resistance to bacterial canker or peach tree short life (PTSL) were highly susceptible to ARR (Beckman 1998; Beckman et al. 1998; Beckman and Pusey 2001). Natural genetic resistance to ARR does exist in some germplasms of plum and two peach $\times$ plum hybrids ('MP-29' and 'Sharpe') (Beckman et al. 2012). Although the mechanisms of resistance are not known yet, the development of tolerant rootstocks is a priority for stone fruits in the absence of chemical (Wilbur et al. 1972; Savage et al. 1974) or biological control options (Schnabel et al. 2011). Even though there are multiple reports on greenhouse and field assays to study the pathogen, the assays reproducibility has been a challenge and a source of great frustration among Armillaria spp. scientists (Raabe 1979; Mansilla et al. 2001; Raziq and Fox 2005). An in vitro 
screening method was developed that recapitulated the known field resistance of rootstocks selected for almond production in California to A. mellea (Baumgartner et al. 2018). It was proposed that this assay could be a breeders' tool to rapidly identify genetic resistance to ARR. Plantlets of the Prunus spp. accession rooted in agar were inoculated with A. mellea in the culture tube-based assay. In the first month, A. mellea colonized the agar-based medium, and in the second month, the mortality or survival of the tissue was used to determine resistance/susceptibility. Prior to inoculation, extra tubes of plantlets were sorted and rogued to find plants with similar shoot and root growth to enter the assay.

Peach can be more difficult to micropropagate than other Prunus spp., and many unique media formulations were required for rooting peach (Kalinina and Brown 2007; Sadeghi et al. 2015). In the Baumgartner et al. (2018) tube-based assay, some resistant cultivars displayed high mortality levels, which were purportedly due to high inoculum pressure overtaking the plant. Plant roots in tubes of semi-solid agar medium grown under anoxic conditions were non-lignified (herbaceous) and lacked some structures of well-developed root tissues. Baumgartner et al. (2018) suggested that biological improvements to the co-culture assay should include plants with developed woody roots and control of inoculum density. In most woody plants, roots in semi-solid agar are thicker and lack secondary branching resulting in increased mortality as the plant ages (Economou 2013). In several endemic Australian species of woody shrubs, oxygen in the root zone was increased when switching from agar to porous agar, to agar/sand mix, to sand/peat/perlite mixture in a series of experiments that concomitantly increased oxygenation and rooting (Newell et al. 2003). In Cercis, the anatomy of in vitro roots in agar had swollen cortical cells and less developed vascular systems compared with roots developed ex vitro in soilless mix (Hartman et al. 2018). A phenolic foam, Oasis ${ }^{\circledR}$ IVE, was configured for this purpose and has been shown to improve rooting in both woody and herbaceous species (Adelberg et al. 2015, 2017; Nicholson et al. 2020). An improved assay system would be desirable for testing germplasm more relevant to peach production in the southeastern USA.

Our current work advances an ARR co-culture system that uses an aerated substrate, Oasis ${ }^{\circledR}$ IVE, for improved root cultures prior to inoculation. This study included rooting of peach and several other Prunus selections that are relevant to ARR resistance for the southeastern USA in a common rooting medium. The goal of this experiment was to advance the methodology suggested by Baumgartner et al. (2018) by (1) eliminating rouging of large numbers of plants prior to inoculation, (2) allowing root growth in a more aerated medium for better root development, (3) growing resistant and susceptible plants in the same vessel exposed to similar fungal pressure, and (4) confirming symptom development in known susceptible rootstock in a time course to establish a correct timing for assessment.

\section{Material and Methods}

This project had two experiments: first, a preliminary experiment observed rooting of a range of rootstocks on the Oasis ${ }^{\circledR}$ IVE in a common environment, and second was the inoculation experiment of two rootstocks, resistant MP-29 and susceptible GF305 in a common garden experiment with A. mellea.

Shoot cultures of Prunus persica $\times$ P. umbellata cv. MP-29 and Prunus maackii 26e (Musser Fruit Tree Research Center, Seneca, SC) were established from dormant wood of mature trees collected in January. Stems (20 to $30 \mathrm{~cm}$ ) were wrapped in moist newspaper and stored in polyethylene bags at $4^{\circ} \mathrm{C}$ until bud sterilization in February and March. Dormant budwood was washed under running tap water, and single buds were cut at the internodes, washed with dilute Ivory liquid detergent, and rinsed twice in tap water. A "chip bud" was removed by cutting at the base and longitudinally severing the bud from stem with a small piece of attached wood. The "chip bud" was dipped in $70 \%$ ethanol for $1 \mathrm{~min}$ and rinsed in deionized/distilled water, then immersed in $10 \%$ bleach $(6.25 \% \mathrm{NaOCl}$, Clorox Company, Oakland, CA) for $10 \mathrm{~min}$, and rinsed twice in sterile distilled water with agitation. Remaining wood, bud scales and outer leaves were removed by peeling back, one-at-a-time, until only a few primordia were remaining, and the bud was greater than $3 \mathrm{~mm}$ in length. Excised buds were placed in $25 \times 95-\mathrm{mm}$ Baxter shell vials containing $20 \mathrm{~mL}$ Murashige and Skoog medium (MS; Murashige and Skoog 1962 Phytotechnology Laboratories, Shawnee, KS; Table 1). The medium $\mathrm{pH}$ was brought to 6.2 using $1 \mathrm{~N} \mathrm{NaOH}$ in this and the latter experiments. Shoot tip culture was maintained by monthly transfer as lateral shoots developed. 'GF 305' was prepared in a similar manner, except the stock plants were maintained in a greenhouse and green shoot tips were subjected to bleach disinfestation procedure.

Aseptic cultures of 'Guardian ${ }^{\circledR}$ ', P. munsoniana, and $P$. cerasifera were established by stratifying and germinating seeds in embryo culture (Sinclair and Byrne 2003). At least 20 open pollinated fruits per accession were collected and stored at $4^{\circ} \mathrm{C}$ until needed. Standard sterilization and culture procedures were applied (Rizzo et al. 1998). In short, fruit was surface sterilized by soaking for $10 \mathrm{~min}$ in each $20 \%$ bleach and $70 \%$ ethanol. The sterilized fruit remained in aseptic condition in a laminar flow hood, the ovules were extracted from the mesocarp, seed coats removed, and the embryos were placed into shell vials containing $10 \mathrm{~mL}$ of Woody Plant 
Table 1. Nutrients in media were based on modifications of Murashige and Skoog (MS 1962), half strength MS, Quoirin and Lepoivre (QL 1977), and a new Prunus medium (NPM) compared as dissimilar and common nutrient concentrations

\begin{tabular}{|c|c|c|c|c|c|}
\hline & MS $1962^{1}$ & One-half $\mathrm{MS}^{1}$ & $\mathrm{QL}^{1}$ & NPM & $\begin{array}{l}\text { NPM- } \\
\text { rooting }\end{array}$ \\
\hline \multicolumn{6}{|l|}{ Nutrient (mM) } \\
\hline $\mathrm{NH}_{4}$ & 20.6 & 10.3 & 5 & 10 & 10 \\
\hline $\mathrm{NO}_{3}$ & 39.4 & 19.7 & 33 & 20 & 20 \\
\hline $\mathrm{K}$ & 20 & 10 & 19.8 & 10 & 10 \\
\hline $\mathrm{PO}_{4}$ & 1.25 & 0.63 & 2 & 1.3 & 1.3 \\
\hline $\mathrm{Ca}$ & 3.0 & 1.5 & 5.1 & 2.6 & 2.6 \\
\hline $\mathrm{Mg}$ & 1.5 & 0.75 & 1.5 & 1.5 & 1.5 \\
\hline $\mathrm{SO}_{4}$ & 1.7 & 0.85 & 1.6 & 2.75 & 2.75 \\
\hline $\mathrm{Cl}$ & 6.0 & 3.0 & 0 & 0.1 & 0.1 \\
\hline \multicolumn{6}{|l|}{ Nutrient $(\mu \mathrm{M})$} \\
\hline $\mathrm{Mn}$ & 100 & 50 & 4.5 & 45 & 45 \\
\hline I & 5 & 2.5 & 0.5 & 5 & 5 \\
\hline \multicolumn{6}{|l|}{ PGR's $(\mu \mathrm{M})$} \\
\hline BA & 2.2 & 2.2 & 2.2 & 0 & 0 \\
\hline IBA & 0.025 & 0.025 & 0.025 & 0 & 15 \\
\hline GA & 0.15 & 0.15 & 0.15 & 0 & 0 \\
\hline Kin & 0 & 0 & 0 & 10 & 0 \\
\hline \multicolumn{6}{|l|}{ Sugar (mM) } \\
\hline Sucrose & 83.3 & 83.3 & 0 & 0 & 83.3 \\
\hline Fructose & 0 & 0 & 83.3 & 83.3 & 0 \\
\hline \multicolumn{6}{|c|}{ Organic acids $\left(\mathrm{mg} \mathrm{L}^{-1}\right)$} \\
\hline Ferulic acid & 0 & 0 & 1 & 1 & 1 \\
\hline Ascorbic acid & 0 & 0 & 2 & 2 & 2 \\
\hline \multicolumn{6}{|c|}{ Common nutrients $(\mu \mathrm{M})$} \\
\hline $\mathrm{B}$ & 100 & 50 & 100 & 100 & 100 \\
\hline $\mathrm{Cu}$ & 0.1 & 0.5 & 0.1 & 0.1 & 0.1 \\
\hline $\mathrm{Co}$ & 0.1 & 0.05 & 0.1 & 0.1 & 0.1 \\
\hline $\mathrm{Fe}$ & 100 & 50 & 100 & 100 & 100 \\
\hline Mo & 1 & 0.5 & 1 & 1 & 1 \\
\hline $\mathrm{Zn}$ & 30 & 15 & 30 & 30 & 30 \\
\hline \multicolumn{6}{|l|}{$\begin{array}{l}\text { Common organic } \\
\left(\mathrm{mg} \mathrm{L}^{-1}\right)\end{array}$} \\
\hline Agar & 8000 & 8000 & 8000 & 8000 & 8000 \\
\hline Inositol & 100 & 50 & 100 & 100 & 100 \\
\hline Glycine & 2 & 1 & 2 & 2 & 2 \\
\hline Thiamine & 1 & 0.5 & 1 & 1 & 1 \\
\hline Nicotinic acid & 1 & 0.5 & 1 & 1 & 1 \\
\hline Pyridoxine & 1 & 0.5 & 1 & 1 & 1 \\
\hline
\end{tabular}

${ }^{1}$ As modified from Kalinina and Brown (2007) for Prunus spp. and 'GF 305' peach

Medium (WPM; Lloyd and McCown 1981 Phytotechnology Laboratories). Racks of vials containing medium and embryos were placed in cardboard boxes, sealed in large plastic bags, and stratified in the dark at $4^{\circ} \mathrm{C}$ for approximately $10 \mathrm{wk}$, after which time they were removed and placed under fluorescent lighting at approximately $115 \mu \mathrm{mol} \mathrm{s} \mathrm{m}^{-1} \mathrm{~m}^{-2}$ with a $16-\mathrm{h}$ photoperiod at $28 \pm 1^{\circ} \mathrm{C}$ to induce germination in a laboratory clean room (positive pressure with HEPA filters constantly recirculating air within clean room). After approximately $3 \mathrm{wk}$, plantlets with well-developed shoots and roots were used for establishment of the agar-based stock plants. Since each seed of 'Guardian ${ }^{\circledR}$ ' is a product of open pollination 
(though primarily self-pollination), micropropagation had to be optimized before the accessions with best micropropagation ability were chosen for subsequent experiments. Three seedling clones from the same mother tree were arbitrarily assigned a letter identifier to track performance during experimentation (Y, F, and $\mathrm{AG}) . P$. cerasifera and $P$. munsoniana seedlings were first inoculated in vitro with A. mellea following Baumgartner et al. (2018) protocol, and seedlings that exhibited tolerance to ARR, e.g., P. cerasifera 20-3, 20-4 and 14-1, and P. munsoniana 59-1, were used for establishing agar-based stock plants.

Shoot tips were maintained by transfer every 4 to $8 \mathrm{wk}$ to $40 \mathrm{~mL}$ fresh medium in Magenta GA/7 vessels (Magenta Corp., Chicago, IL) placed under fluorescent lighting at $40 \mu \mathrm{mol} \mathrm{s}{ }^{-1} \mathrm{~m}^{-2}$ with a $16-\mathrm{h}$ photoperiod at $22 \pm 1{ }^{\circ} \mathrm{C}$ in a laboratory clean room. The choice of media depended on the species listed in Kalinina and Brown (2007) as follows: $P$. persica genotypes were sub-cultured on a modification of QL (Quoirin and Lepoivre 1977), and other Prunus species $P$. maackii, $P$. munsoniana, and $P$. cerasifera were subcultured on MS or one-half MS (Table 1). P. persica remained on QL, but the other Prunus species were switched to a New Prunus Medium (NPM; Table 1) to improve shoot quality.

Rooting was induced on shoots with NPM-R medium (without IAA and Kinetin; Table 1) using a 4-d initiation culture on $15 \mu \mathrm{M}$ IBA agar-gelled medium (as in Kalinin and Brown 2007). After $4 \mathrm{~d}$, shoot tips were transferred to phenolic foam Oasis ${ }^{\circledR}$ IVE (Smithers-Oasis Company, Kent, $\mathrm{OH}), 30$ cell blocks infused $150 \mathrm{~mL}$ liquid NPM$\mathrm{R}$ medium without PGRs or agar in the RV 750 rectangular polycarbonate culture vessel (EightomegaFIVE, Santa Paula, CA). Shoot tips were placed in every other cell using a fine forceps to carefully insert the shoot into the dibble hole. The arrangement of genotypes varied in the two experiments, with two genotypes planted in each vessel.

Rooting in phenolic foam A preliminary rooting experiment was conducted with 15 of the 30 cells in the IVE block planted and the two genotypes divided across the short side of the rectangular RV 750 (one side of the vessel with seven shoots and the other side with eight shoots). The pairings of genotypes were as follows: P. cerasifera 20-4 (DPRU 2101) and P. maackii 26-e, P. cerasifera 20-3 and 'MP-29', $P$. munsoniana 59-1 and P. cerasifera 14 (DPRU 2314)-1, P. persica 'GF 305' and Guardian ${ }^{\circledR} \mathrm{F}$, and Guardian ${ }^{\circledR} \mathrm{Y}$ and AG. There were two vessels for each pair of genotypes. After $30 \mathrm{~d}$ of growth, the percent of shoots with roots were scored. The amount of roots was described on a qualitative score (3-many roots extended outside of the cell, 2-a few roots were seen at the exterior of the cell, 1 -root initials were found at the base of the plant, 0 - no roots were observed). Roots were fixed, sectioned, and stained for histological examination. An 'MP-29' plant from the agar-based stock plants was similarly prepared for histology.

Root histology Peach root segments were harvested from noninoculated 'MP-29' control plants growing in a semi-solid agar medium and growing in IVE and stored in $1 \times$ phosphate-buffered saline (PBS) (Boston Bioproducts, Ashland, MA) for processing. Root segments were fixed for cross-sectioning in formalin-acetic acid-alcohol (FAA) solution (63\% ethanol (Pharmco, Richardson, TX), 5\% glacial acetic acid (Fisher Scientific, Fair Lawn, NJ), 5\% formalin [37\% formaldehyde] (MilliporeSigma, Saint Louis, MO)) for $16 \mathrm{~h}$ and then transferred to $70 \%$ ethanol for another $16 \mathrm{~h}$. Roots were further processed for paraffin-wax embedding using a Leica ASP300 enclosed tissue processor (Leica Microsystems, Wetzlar, Germany). Processed roots were placed in embedding cassettes, and molten paraffin wax (Richard-Allan Scientific, Kalamazoo, MI) was poured into the cassettes to embed the root sections. Roots were sectioned to a thickness of $15 \mu \mathrm{m}$ on a Leica RM 2165 microtome (Leica Microsystems). Sections were placed, floating, onto $35^{\circ} \mathrm{C}$ distilled water for $5 \mathrm{~min}$ and then transferred to microscope slides. Slides were incubated at $32^{\circ} \mathrm{C}$ for $24 \mathrm{~h}$ with a Premiere Slides Warmer (model: XH-2001) (C\&A Scientific, Manassas, VA). Slides were deparaffinized and rehydrated by submergence with the following treatments: (1) $100 \%$ xylene (VWR, Amresco, Solon, OH) for 2 min (repeat three times), (2) $100 \%$ ethanol for 2 min (repeated two times), (3) $95 \%$ ethanol for $2 \mathrm{~min}$ (repeat two times), (4) quickly submerged in distilled water (repeated three times).

Root cross sections were cleaned by submergence in a $3: 1$ solution of $1 \times$ PBS and $16 \%$ paraformaldehyde (MilliporeSigma) for $10 \mathrm{~min}$ and then rinsed with a $1 \times$ PBS solution. Sections were washed with a $20-\mathrm{mM}$ glycine (Phytotechnology Laboratories) solution for $15 \mathrm{~min}$. Next, the samples were washed twice, submerged in a $1 \times$ PBS solution, and placed on a Corning orbital shaker (Corning Inc., Corning, NY) at 60 RPM for 5 min each. Samples were stained by submergence in a $1 \times$ PBS solution containing $1 \%$ propidium iodide and placed in the dark on an orbital shaker at $60 \mathrm{RPM}$ for $25 \mathrm{~min}$. Sections were washed in $1 \times$ PBS for 5 min on an orbital shaker at 60 RPM. Excess PBS solution was removed, and $25 \mu \mathrm{L}$ of a 1:1 $20 \mathrm{mM}$ glycine to $1 \times$ PBS seating solution was applied directly on top of the samples. A coverslip was placed over the samples and sealed with a Sally Hansen Insta Dri, clear fingernail polish (Sally Hansen, New York, NY). Sections were imaged at the Clemson Light Imaging Facility on a Leica SPE confocal microscope using LASX acquisition software (Leica Microsystems).

Fungal inoculation A. mellea was chosen over other species due to demonstrated suitability to distinguish susceptible from resistant phenotypes in culture assays (Baumgartner et al. 
2018). Phenolic foam about $1 \mathrm{~cm}$ in thickness was cut to fit the bottom of RV 750 vessel $(15 \times 10 \times 10 \mathrm{~cm}$ Oasis $\AA$; SmithersOasis Co.), and 12 equally spaced holes were cut into each foam using a $1-\mathrm{cm}$ cork borer. A total of $70 \mathrm{~mL}$ of $3 \%$ malt extract broth (VWR, Amresco) containing 0.9\% Bacto Peptone (Beckton, Dickinson and Co., Sparks, MD), 3\% dextrose (Fisher Scientific), and half strength Linsmaier and Skoog nutrients (Caisson Laboratories, Smithfield, UT) were added to the RV 750 vessels before autoclaving. A. mellea isolate SCOOi149 (obtained in 2000 from a symptomatic tree in Cooley Springs, SC, USA) was recovered from filter paper storage and cultured on $3 \%$ malt extract (VWR) containing 0.9\% Bacto Peptone (Beckton, Dickinson and Co.), 3\% dextrose (Fisher Scientific), and 1.5\% agar (Beckton, Dickinson and Co.) for $3 \mathrm{wk}$. One-centimeter-diameter plugs were recovered from the advancing margins of colonies and placed 'right side up' into the preformed holes of the sterilized foam. RV 750 vessels were sealed using PVC sealing film and incubated for $3 \mathrm{wk}$ in the dark at $22^{\circ} \mathrm{C}$ in the laboratory prior to addition of plants.

Shoot tips of two genotypes (susceptible $P$. persica 'GF 305 ' and resistant peach $\times$ plum hybrid 'MP-29'; Beckman et al. 2012) were prepared in the 4-d root initiation culture on NPM-R. IVE blocks were infused with $150 \mathrm{~mL}$ of liquid NPM (without PGRs or agar). 'GF 305' and 'MP-29' were planted in the same IVE blocks for inoculation with 12 shoots per block consisting of six shoots planted every other cell along the length of the vessel (two rows of three), with the center row left empty, and the other genotype planted down the other long side of the vessel. The experiment consisted of eight vessels, each containing six shoots of each genotype. Four of the eight vessels were selected at random for inoculation; the other four blocks of rooted plants were the control.

Five weeks after initiation, the inoculum and rooted plants were ready to be combined (Fig. 1). The IVEs containing plants were refreshed by filling the vessel with half strength MS medium without sugar, organic compounds, or PGRs, then pouring off the excess liquid. The four IVEs selected for inoculation were lifted with a steel spatula and placed in a companion vessel overlaying the solid block IVE infused with inoculum. The four IVEs containing the control plants were similarly refreshed. The entire experiment was repeated twice.

Observations of the experimental vessels were made $4 \mathrm{wk}$ after inoculation with $A$. mellea. Shoot survival (number of live shoots per plant) was scored based on visibly leafy, green shoots. When the first symptoms appeared at $6 \mathrm{wk}$ after inoculation, a disease scoring system was initiated. Vessel lids were removed to closely observe the shoots, and the health of each plant was assessed as follows: 5-no symptoms of decline; 4-a few leaves with necrotic tips; 3-half of the leaves showing necrosis; 2 -half of the leaves were dead and widespread necrosis on the others; 1 -almost the entire plant was dead; and 0 - the whole plant was dead. Before returning the vessel lids, leaves that extended past the outer perimeter of the vessels were trimmed, and $7 \mathrm{~mL}$ of one-half
Figure 1. 'GF 305' and 'MP-29' were rooted in the same vessel (A). After $5 \mathrm{wk}$, plants rooted well in Oasis ${ }^{\circledR}$ IVE phenolic foam $(B)$. During that same time, Armillaria mellea inoculum was prepared in phenolic foam wafer in separate RV 750 vessels $(C)$. At week 5 under aseptic conditions, plants rooted in phenolic foam $(A, B)$ were placed to overlay the inoculum $(C)$ to start $10 \mathrm{wk}$ of incubation.
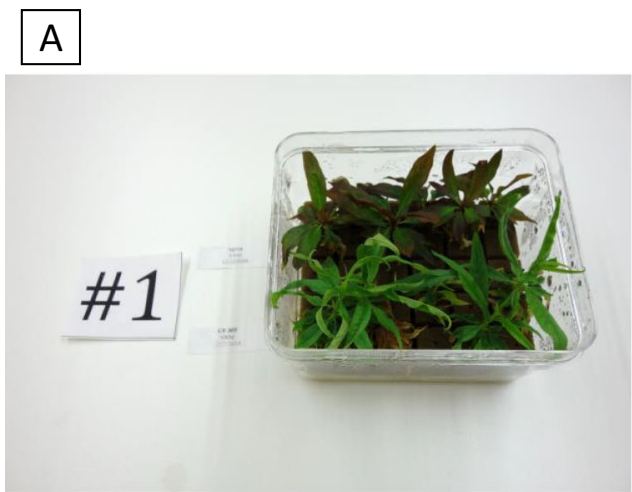

$\mathrm{C}$

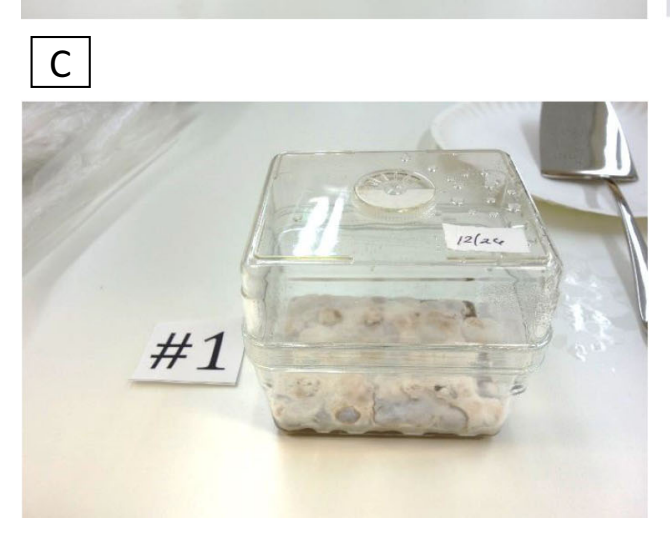

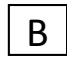

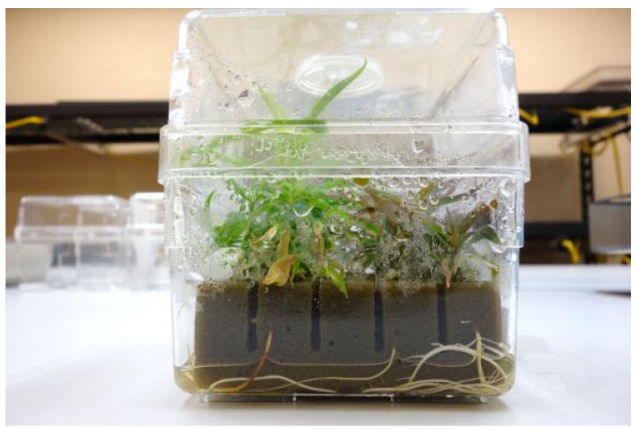


MS medium (without sugar, organic compounds or PGRs) was added to each vessel. The scoring process, trimming, and media supplement were repeated 6,8 , and $10 \mathrm{wk}$ after inoculation. The rooting experiment was a one-way analysis of percent rooting and the amount of roots (as scored by rating). In the fungal co-culture, the analysis of variance was performed on the plant health score and the percent mortality (no. of dead plants per number of plans survived at time of fungal introduction) to determine the significance of genotype, A. mellea treatment, and the interaction, with repeated measures on three dates 2 wk apart. Factors with $>95 \%$ significance are discussed.

\section{Results and Discussion}

Rooting All ten genotypes had good rates of survival after 5 wk on the IVE (Table 2). The plums and the one peach $\times$ plum hybrid rootstock rooted well (80 to $100 \%)$ and had a large amount of roots ( 2 to 3 on a 3 -point scale) in the phenolic foam with the NPM common nutrient medium (Table 2). The amount of rooting was described on a qualitative scale because quantitatively removing roots from the phenolic foam would cause excessive root loss. Open pollinated seedlings taken from a single tree of Guardian $®$ peach rootstock rooted very differently. Guardian® (Y) rooted well (80\% with 2.7 score), but Guardian® $\mathrm{F}$ and $\mathrm{AG}$ rooted at a low rate $(13 \%$ and $15 \%$ ) and $A G$ had a small amount of roots (with score of 1 ). The chokecherry was intermediate in rooting response to plums and peaches.

When comparing roots grown in an aerated condition in phenolic foam, distinct xylem and protoxylem were observed but were absent in roots grown in anoxic agar (Fig. 2A, B). An observation of fewer cells with secondary thickenings in root xylem from foam compared with those grown on agar (Fig.
2C, D) has two possible explanations: (1) there were fewer vessels with narrowed diameters or (2) fewer of the tapered end caps were cut in cross section because xylem vessels were longer. Xylem vessel length is rarely directly measured and was often the neglected dimension in studies of vessel architecture (Jacobsen et al. 2012). Either or both interpretations of altered xylem architecture would allow greater hydraulic conductance by roots grown on foam. In grafted field plants, the vegetative growth of peaches is often controlled by hydraulic conductance of rootstock (Tombesi et al. 2010). The phenolic foam permitted growth of better developed roots than the semi-solid agar gel. The differentiation of xylem tissues on phenolic foam better resembled what would be found in planta (Foster and Gifford 1974).

Inoculation with $A$. mellea Following $5 \mathrm{wk}$ of in vitro rooting in the same vessels, 97\% of the peach $\times$ plum hybrid 'MP-29' and $77 \%$ of $P$. persica 'GF 305 ' had vigorous shoots. 'MP-29' leaves were purple, as typical in field culture (Fig. 1). During the subsequent 6-wk period of fungal co-culture, further losses in 'GF 305' and 'MP-29' were insignificant in the control (Fig. 3). Four weeks after inoculation A. mellea grew upward, permeating the aerated spaces of the foam matrix containing the rooted plantlets. Roots grew through the foam matrix into the aerated spaces surrounding the foam. Leaves on control 'MP-29' were now green, and the inoculated shoots were still purple. It is speculated that at transfer, the anthocyanin pigmentation was due to an incipient water stress. At the time, the plants were inoculated; all of the blocks were soaked in fresh, one-half strength medium. This may have relieved the water stress, but in the inoculated foam blocks, the fungus used the water first (or blocked the water uptake). In 'GF 305', shoot growth was prolific and the large leaves showed some interveinal yellowing (typical of nutrient deficiency) in both control and inoculated plants.
Table 2. Rooting percentage of Prunus genotypes on Oasis ${ }^{\circledR}$ IVE phenolic foam. The amount of root growth was scored as follows: 3-many roots extended outside each cell; 2 - a few roots at the exterior of each cell; 1 root initials at the base of the plant; or 0-rooting was not observed

\begin{tabular}{|c|c|c|c|c|c|}
\hline Species & Genotype & Common name & $\begin{array}{l}\text { Survival } \\
\%\end{array}$ & $\begin{array}{l}\text { Rooting } \\
\%\end{array}$ & $\begin{array}{l}\text { Amount of } \\
\text { roots }\end{array}$ \\
\hline Prunus cerasifera & $14 / 4$ & Myrobalan plum & $100 \mathrm{a}$ & $100 \mathrm{a}$ & $2.9 \mathrm{a}$ \\
\hline $\begin{array}{l}\text { P. persica } \times \\
\text { P. umbellata }\end{array}$ & 'MP-29' & $\begin{array}{l}\text { Peach plum } \\
\text { hybrid }\end{array}$ & $100 \mathrm{a}$ & $94 a$ & $2.7 \mathrm{ab}$ \\
\hline P. cerasifera & $20-3$ & Myrobalan plum & $100 \mathrm{a}$ & $93 a$ & $2.0 \mathrm{bc}$ \\
\hline P. cerasifera & $20-4$ & Myrobalan plum & $100 \mathrm{a}$ & $88 \mathrm{a}$ & $2.4 \mathrm{abc}$ \\
\hline P. munsoniana & $59 / 1$ & Wild goose plum & $100 \mathrm{a}$ & $80 \mathrm{ab}$ & $2.4 \mathrm{abc}$ \\
\hline P. persica & Guardian ${ }^{\circledR} Y$ & Peach & $100 \mathrm{a}$ & $80 \mathrm{ab}$ & $2.7 \mathrm{ab}$ \\
\hline P. maackii & $26 \mathrm{e}$ & Chokecherry & $100 \mathrm{a}$ & $71 \mathrm{ab}$ & $1.9 \mathrm{bc}$ \\
\hline P. persica & GF 305 & Peach & $80 \mathrm{~b}$ & $42 b c$ & $1.6 b c$ \\
\hline P. persica & Guardian ${ }^{\circledR} \mathrm{F}$ & Peach & $73 b$ & $15 \mathrm{c}$ & $2.5 \mathrm{abc}$ \\
\hline P. persica & $\begin{array}{l}\text { Guardian }{ }^{\circledR} \\
\text { AG }\end{array}$ & Peach & $100 \mathrm{a}$ & $13 \mathrm{c}$ & $1 \mathrm{c}$ \\
\hline
\end{tabular}

Different letters within a column denote mean separation by Tukey's HSD $(P=0.05)$ 
Figure 2. Root sections 'MP-29' grown on agar $(A)$ and Oasis phenolic foam $(B)$ were anatomically distinct. Xylem (x) from root on agar lacks the pentarchal arrangement of protoxylem (px) poles observed in root grown on foam. The endodermis (en) is plainly visible in an agargrown roots, but not distinct in root grown on foam. Cells of the cortex (c) were more swollen when grown on agar then in foam. Closer examination of the xylem vessels from root in agar $(C)$ had internal thickening that was less prevalent in xylem cells from foam $(D)$, as indicated by arrows.
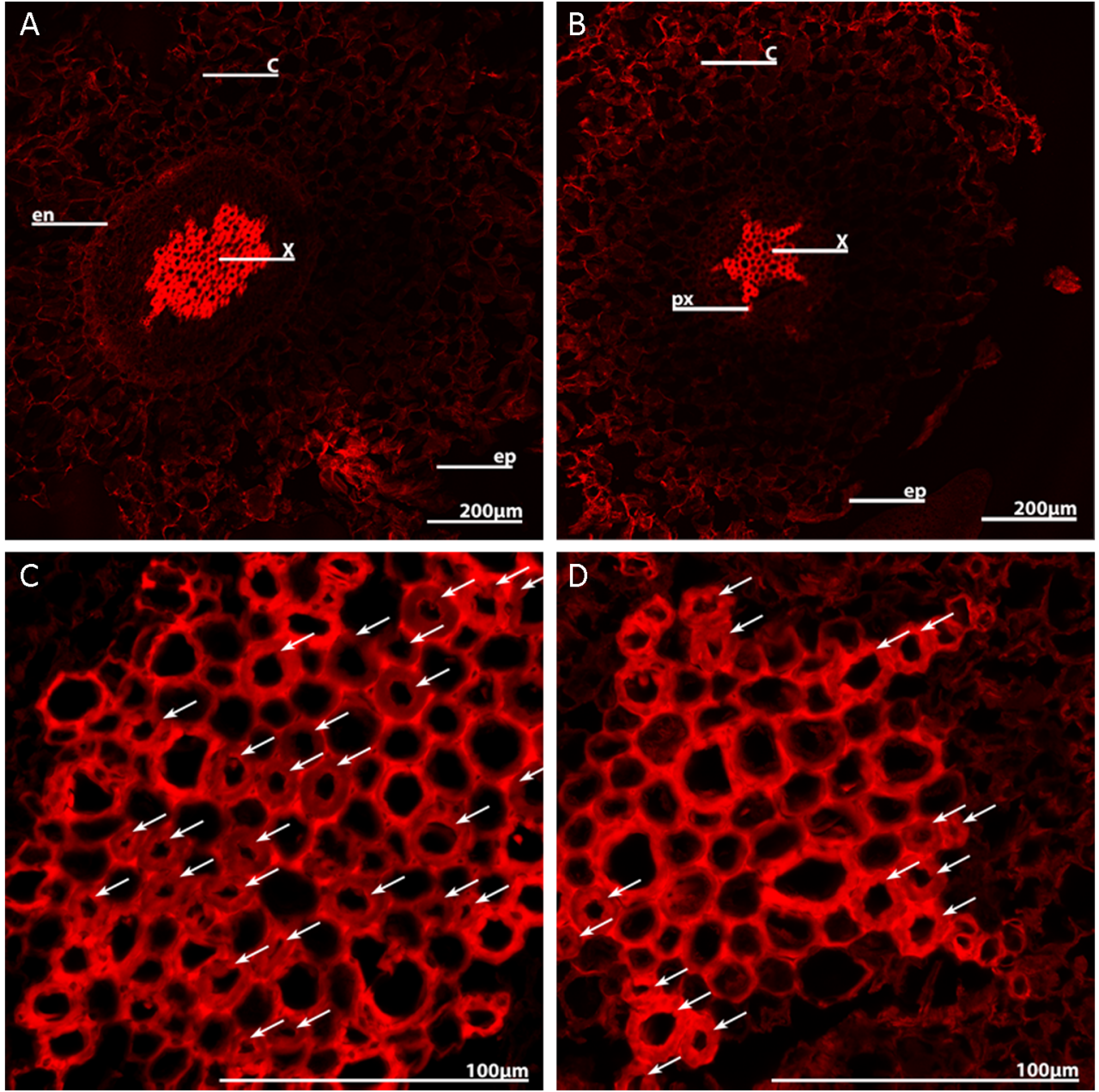

Six wk after the inoculation with $A$. mellea, differences in response of the two genotypes were measured (Fig. 3). Both 'MP-29' and 'GF 305' controls had not changed in their appearance from 4-wk plants. In 'MP-29', most of the treated plants had purple leaves and were vigorous, a few had dead shoot tips or had lost a leaf, and one had several dead leaves. All treated 'GF 305' plants were showing signs of decline with more than half being chlorotic and necrotic, a few were nearly dead, and several had died. The putatively disease resistant 'MP-29' had not declined under treatment conditions. Larger leaves that protruded beyond the edge of the vessel needed to be removed before closing the vessels' lids.

The difference between the putatively resistant 'MP-29' and the susceptible 'GF 305' was visibly apparent after $8 \mathrm{wk}$ of treatment conditions (Fig. 4). 'MP-29' control had not changed in their appearance from four (or $6 \mathrm{wk}$ ) observations, although one plant had died. At wk 8, most of the control plants in 'GF 305' had not changed their appearance from wk 6 , but a couple had dead shoot tips or had lost a leaf, one was mostly chlorotic, and one was partly necrotic and nearly dead. Most of the treated 'MP-29' plants were similar to the week 6 observations, a few had shoot tip dieback or lost a leaf, a few plants were chlorotic and necrotic, some were nearly dead, and one had died. At $8 \mathrm{wk}$ after inoculation, symptoms on 'MP-29' became apparent. Most of the 'GF 305' plants had died, a few were plants were mostly chlorotic or necrotic, and near dead. Roots of both genotypes were clearly visible in intimate association with A. mellea (Fig. 5). After $10 \mathrm{wk}$ of co-culture plants were larger, and the 'MP-29' and 'GF 305' control had not changed very much in appearance from 4- to 8 -wk plants. However, the decline of plants treated with A. mellea continued with many 'MP-29' in decline and most of the 'GF 305' were dead.

Mortality Five weeks of rooting in the phenolic resin followed by $10 \mathrm{wk}$ of fungal treatment is a long time for tissue cultured plants to remain in vessels without transfer. Adding fresh liquid media every 2 wk and trimming very large leaves was needed to keep plants within the confines of the large (750 mL) vessel. None of the 'MP-29' control plants died during the $15 \mathrm{wk}$, although following 8 or $10 \mathrm{wk}$ of cocultivation with $A$. mellea, approximately $15 \%$ loss was documented (Fig. 6). Peach is more difficult to micropropagate, and about $10 \%$ of the control plants were lost during 5 to 
Figure 3. Response of 'GF 305' and 'MP-29' during 6 to $10 \mathrm{wk}$ after inoculation with Armillaria mellea (11 to $15 \mathrm{wk}$ after starting culture). Each individual plant was scored as follows: 5 -no symptoms; 4 - a few leaves with necrotic tips; 3 -half of the leaves showing necrosis; 2 - half of the leaves were dead and widespread necrosis on the others; 1 -almost the entire plant was dead; and 0 the whole plant was dead. Data represent mean scores (with 95\% confidence) for 16 vessels, each containing 12 plants, six plants of each cultivar with the entire experiment repeated twice.

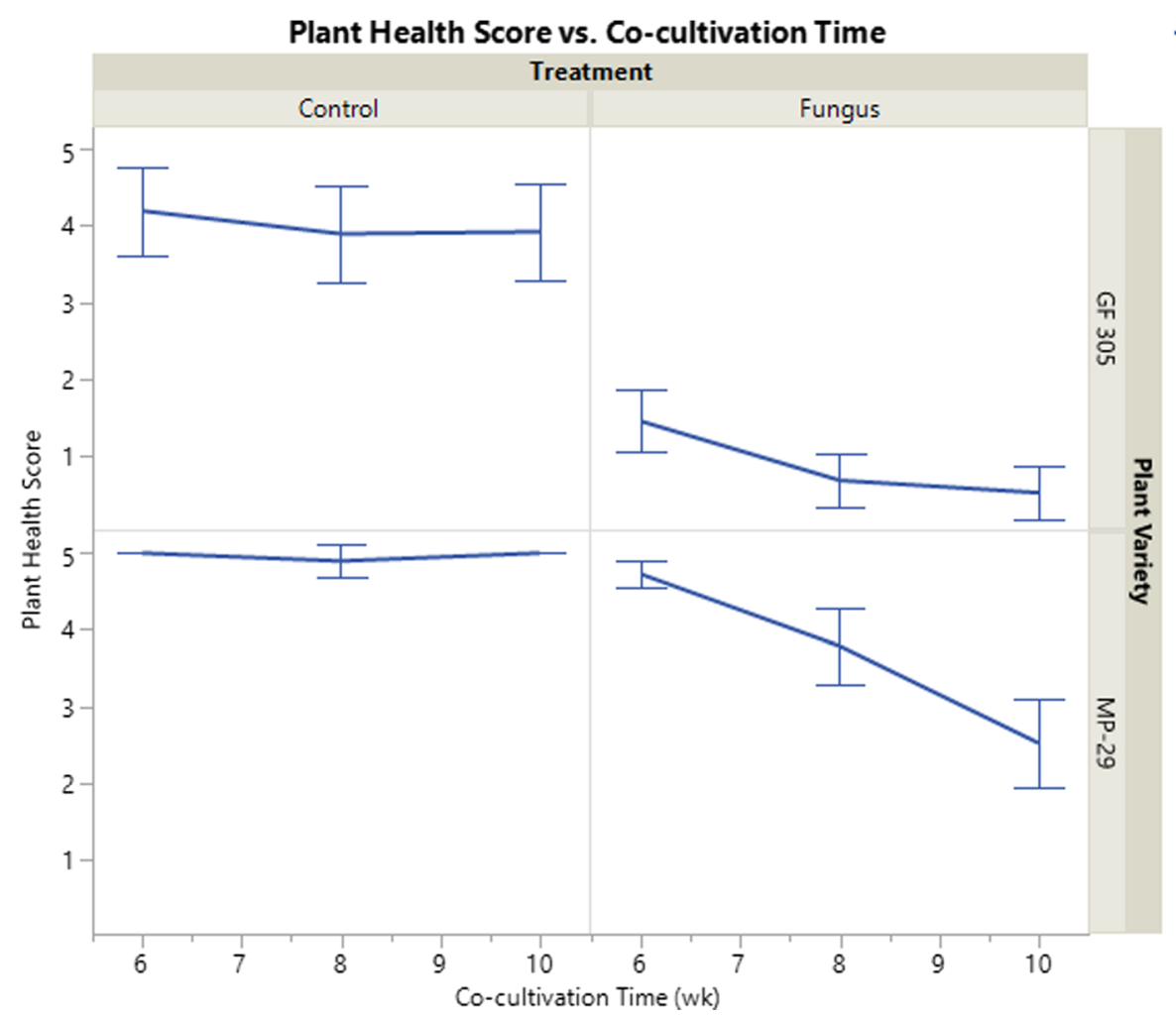

$15 \mathrm{wk}$ without transfer. This was very different from mortality due to a susceptible reaction to Armillaria. Over the same 10- wk period, mortality in 'GF 305' went from approximately $25 \%$ at wk 6 to $80 \%$ at wk 15 .

Figure 4. Co-culture (with vessel lids removed) shown at week 13 (8 wk after the introduction of Armillaria mellea). Fungal mycelium grew upward into the rooting block, and disease symptoms and necrosis were plainly seen on 'GF 305 '. 'MP29' appeared tolerant to the disease pressure and produced its characteristic purple leaves. Plants in the control vessels were thriving. In the $A$ figure, 'MP-29' was shown in the foreground in one replication of the experiment; in the $B$ figure, 'GF-305' was shown in the foreground from the second replication.

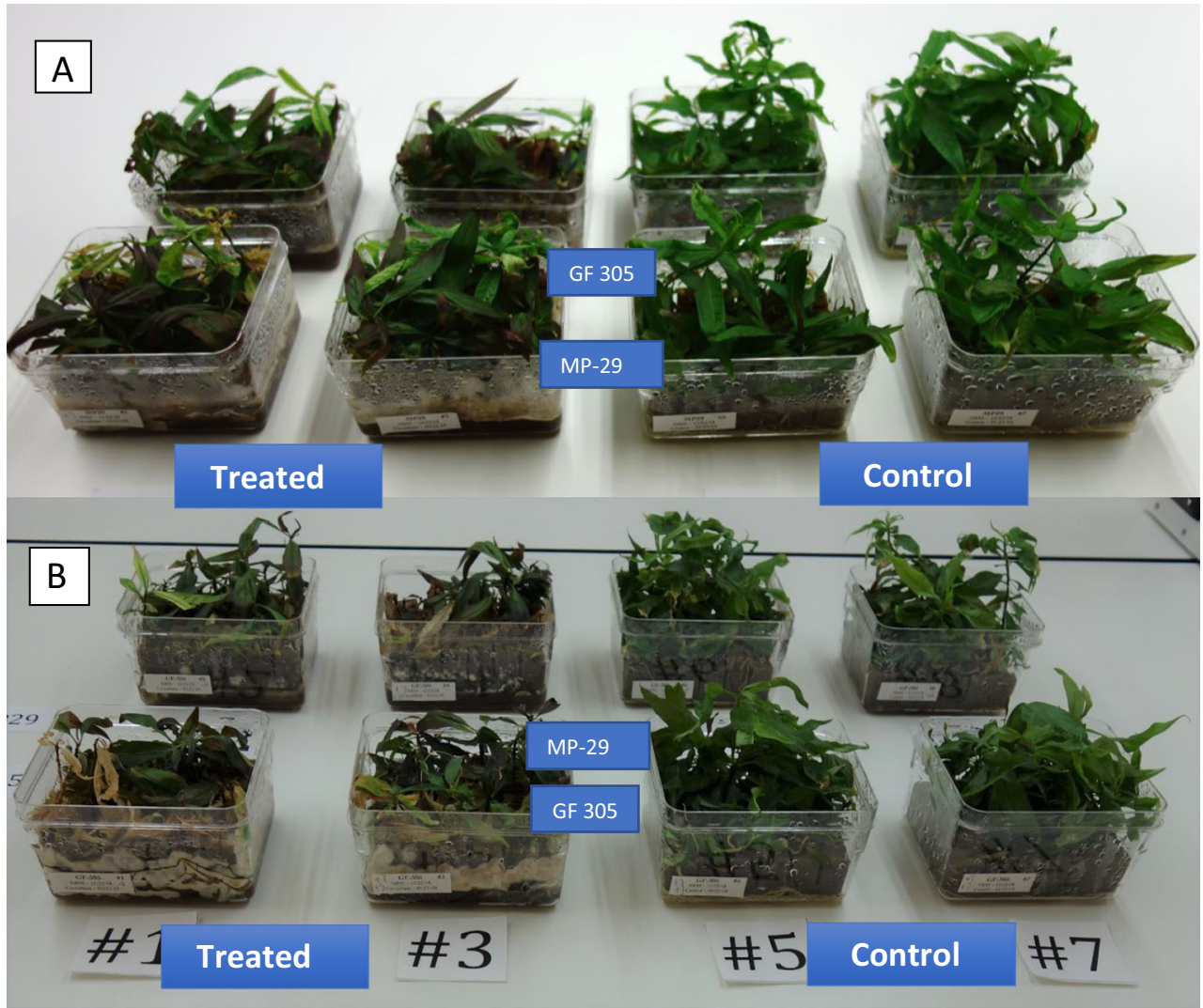


Figure 5. A closer look at shoots (A) of inoculated plants showing five of the the 'GF 305' plants had died, although one was still living. Five of the six 'MP-29' plants were still alive, and four were without symptoms. A side view of the vessel with 'GF 305' showed both plant roots and Armillaria mellea permeated the phenolic foam matrix $(B)$. The reverse side of the vessel showed 'MP-29' with new white roots actively growing while the fungus is rampant $(C)$.
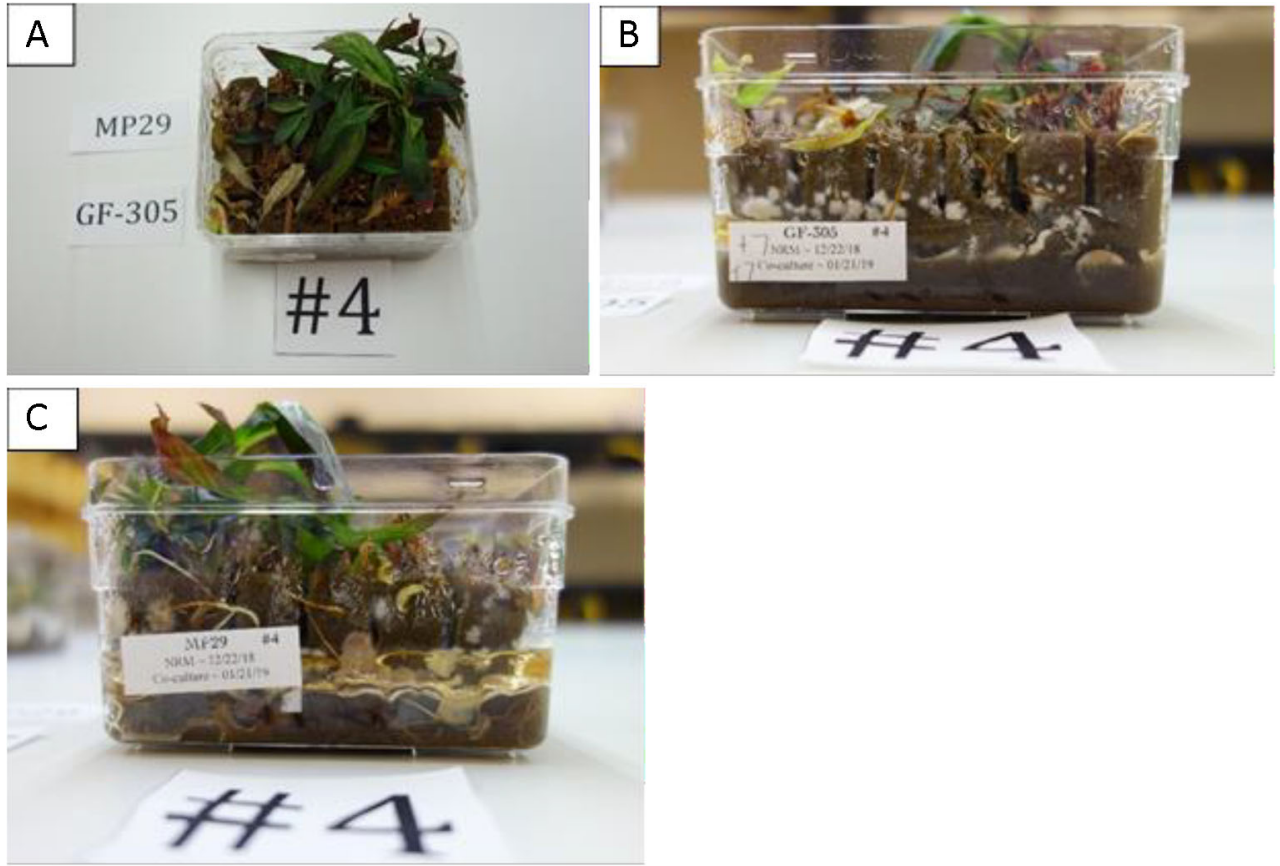

Plantlets rooted in the foam after $15 \mathrm{wk}$ in the presence of fungus were in decline, even the resistant cultivar, but at the same time, almost all the susceptible plantlets were dead. Since many putatively resistant plum genotypes rooted well in the foam matrix, this screening tool will be useful on broader base of germplasm. This work demonstrates a scalable format method to test more germplasm against other causal agents of Armillaria root rot.

Screening germplasm for ARR resistance in tree fruit orchards is a very difficult task for several reasons. The experimental site may not have sufficient inoculum (i.e., insufficient numbers of infected root pieces), and inoculum is not
Figure 6. Response of 'GF 305' and 'MP-29' to during 6 to $10 \mathrm{wk}$ of co-culture with Armillaria mellea (11 to $15 \mathrm{wk}$ after starting culture). The susceptible 'GF 305 ' rootstock showing considerable mortality and a rapid progression to nearly $100 \%$ mortality following $10 \mathrm{wk}$ of fungal coculture. The resistant peach plum rootstock 'MP-29' had no losses after $6 \mathrm{wk}$ of fungal culture and had little mortality at $10 \mathrm{wk}$. Means are shown bound with $95 \%$ confidence.

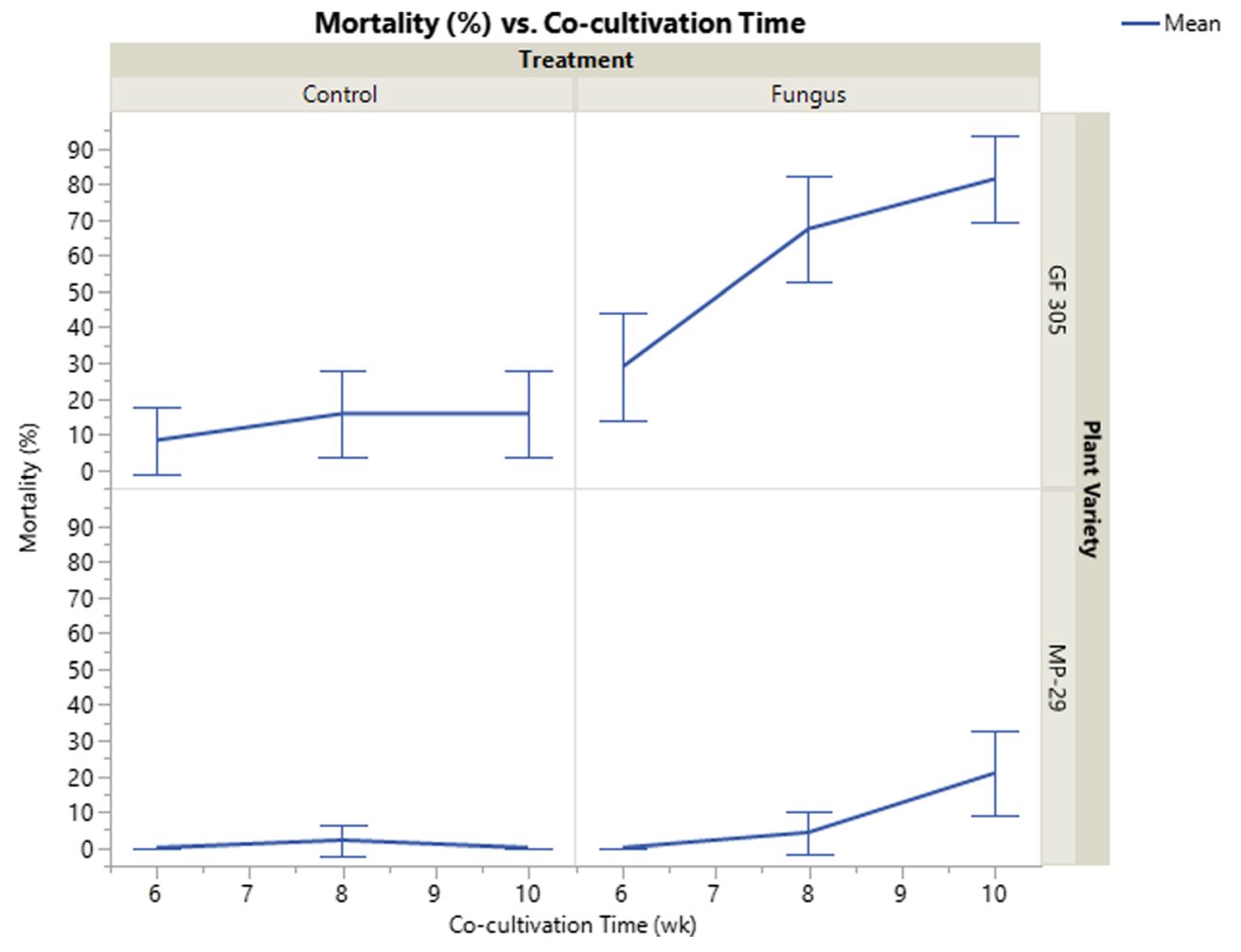


uniformly distributed in the soil. Even large numbers of plant replicates may not be adequate to overcome these limitations. Artificial inoculation with lab-generated inoculum has not proven reliable in the field either (Shaw and Kyle 1991). Therefore, it is critical for breeding programs to adopt and use an assay-based system to screen large numbers of rootstock candidates. But in vitro assay-based approaches do have problems on their own. The fungus and plant cultures were grown together for short periods of time with sucrose as the energy source. It is not yet known if novel germplasm that is selected as resistant during the in vitro screen will confer resistance over years of fungal contact in the orchard. This could only be exacerbated by other stress factors the crop might encounter in the orchard.

Mortality is one clear measure for resistance in assay-based screens, but subjective scales are also useful to follow a pathogen's progression on its host when cultured in artificial medium. Differential responses in shoot quality and mortality were documented over the entire $10 \mathrm{wk}$ of Armillaria treatments. Assaying for resistance should be performed after $8 \mathrm{wk}$ under treatment conditions to see the most pronounced differences in shoot quality and mortality (Fig. 3). This is a similar time frame suggested by Baumgartner et al. (2018) for agarbased test tube assays.

One difficulty in performing this type of work is the unique medium requirements for Prunus spp. and the peach rootstocks in this study. Kalinina and Brown (2007) experienced a similar problem when they tested over a dozen media to develop a screen for viral transmission in ornamental Prunus spp. using 'GF 305 ' as a host. Using the in vitro screening technique of Baumgartner et al. (2018), only plants with similar levels of growth were used and many others were rogued. The method described in this manuscript, with 12 to 15 plants per vessel produces good data from each vessel without sorting. Other researchers have attempted unique multifactor designs and dozens of media formulations to resolve problems in mineral nutrient composition of micropropagation medium for peach rootstock (Alanagh et al. 2014; Kovalchuk et al. 2018). We started with modified media of Kalinina and Brown (2007), but genotypes of interest required further nutrient formulation. The NPM medium was useful for rooting plums, the peach $\times$ plum hybrid, and some peach genotypes. One oddity that stands out was seedling variation in 'Guardian ${ }^{\circledR}$ '. Some vessels appeared to have more or less fungal growth. Having the resistant and susceptible plant genotypes in the same vessel created paired common garden tests of resistance or susceptibility at varying levels of inoculum.

Roots grown in agar are often brittle and do not have adequate water or nutrient uptake (Newell et al. 2003). The foam allowed for better quality root development than roots grown on agar. A variety of porous substrates infused with liquid media have been used for rooting (sand, rockwool, perlite, vermiculite, cellulose plugs, and Floralite plugs). Hypoxia is avoided in a more oxygenated environment resulting in better physiologic functions (Kirdimanee et al. 1995; AfreenZobayed et al. 1999; Newell et al. 2003). Transferring groups of plants to a vessel containing the inoculum requires the plug to remain intact so loose fill material like sand, vermiculite or perlite would not work, and furthermore, these bulk materials can be difficult to sterilize in the autoclave. Rockwool plugs are too large for most applications in tissue culture. Sorbarod cellulose plugs and Floralite cellulose/vermiculite plugs are no longer commercially available. In previous works in our micropropagation program, we have tried all of these materials, including the phenolic foam matrix, and selected Oasis IVE for its ease of use, cleanliness, and sizing considerations.

Acknowledgments The authors would also like to acknowledge David Bishop for his contribution of 'GF 305' tissue cultures at the beginning of this work. The research reported in this publication was conducted using a Leica SPE Confocal microscope, housed in the Clemson Light Imaging Facility (CLIF). We also acknowledge the Animal and Veterinary Sciences Histology Core Facility for their assistance.

Author's contributions JA- designed the co-culture system, helped design the experiment, helped collect data, analyzed the data, and drafted the paper.

JANA - developed co-culture process, initiated shoot cultures and developed Prunus shoot and root culture method, collected data, and assisted in manuscript draft.

SM-performed seedling culture, developed qualitative scale and collected data, and assisted in manuscript draft.

$\mathrm{KG}$-leads ARR program, collected the germplasm, performed seeding culture, and drafted the manuscript.

GS - designed the experiment, produced A. mellea inoculum, and assisted in drafting manuscript.

$\mathrm{PB}$ - produced A. mellea inoculum and assisted in drafting manuscript.

CS - histology, data analysis and assisted in drafting manuscript.

SP-histology.

GR - initiated ARR program, assembled the germplasm, and assisted in drafting manuscript.

Funding This research was funded by Multistate Specialty Crop Block Grant from the US Department of Agriculture, Agriculture Marketing Service Specialty Crop Multistate Project, Short and long-term solutions for Armillaria root rot in Prunus (USDA-AMS-SCMP-2015-10.170). This paper is Technical Contribution No. 6915 of the Clemson University Agricultural Experiment Station and is supported by NIFA/USDA, under project number SC-1700530. This material is based upon work supported by USDA National Institute of Food and Agriculture, under project number SC-1700501. CLIF is supported, in part, by the Clemson University Division of Research, NIH EPIC COBRE Award \#P20GM109094, and NIH SCBiocraft COBRE Award \#5P20RR021949-03.

\section{Compliance with ethical standards}

Disclaimer The content of this material and any opinions, findings, conclusions, or recommendations expressed in this material is solely the responsibility of the author(s) and does not necessarily represent the official views of the National Institutes of Health or the Unites States Department of Agriculture. 
Conflict of interest The authors declare that they have no conflict of interest.

Open Access This article is licensed under a Creative Commons Attribution 4.0 International License, which permits use, sharing, adaptation, distribution and reproduction in any medium or format, as long as you give appropriate credit to the original author(s) and the source, provide a link to the Creative Commons licence, and indicate if changes were made. The images or other third party material in this article are included in the article's Creative Commons licence, unless indicated otherwise in a credit line to the material. If material is not included in the article's Creative Commons licence and your intended use is not permitted by statutory regulation or exceeds the permitted use, you will need to obtain permission directly from the copyright holder. To view a copy of this licence, visit http://creativecommons.org/licenses/by/4.0/.

\section{References}

Adelberg J, Naylor-Adelberg J, Rapaka V (2015) A novel rooting matrix and vessel system resulted in larger plants and faster growth during greenhouse acclimatization of Hydrangea quercifolia 'Sikes Dwarf'. Propag Ornamental Plants 15:89-94

Adelberg J, Naylor-Adelberg J, Rapaka V (2017) Phenolic foam rooting matrices allows faster transfer and more rapid growth of Echinacea plants in greenhouse. In Vitro Cell Dev Biol - Plant 53:546-562

Afreen-Zobayed FA, Zobayed SMA, Kubota C, Kozai T, Hasegawa O (1999) Supporting material affects the growth and development of in vitro sweet potato plantlets cultured photoautotrophically. In Vitro Cell Dev Biol- Plant 35:470-474

Alanagh EN, Garoosi G, Haddad R, Maleki S, Landin S, Gallego PP (2014) Design of tissue culture media for efficient Prunus rootstock micropropagation using artificial intelligence models. Plant Cell Tiss Org Cult 117:349-359

Baumgartner K, Fujiyoshi P, Ledbetter C, Duncan R, Kluepfel D (2018) Screening almond rootstocks for sources of resistance to Armillaria root disease. HortScience 53:4-8

Beckman TG (1998) Developing Armillaria resistant rootstocks for peach. Acta Hort 65:219-224

Beckman TG, Okie WR, Nyczepir AP, Pusey PL, Reilly CC (1998) Relative susceptibility of peach and plum germplasm to Armillaria root rot. HortScience 33:1062-1065

Beckman TG, Chapparo JX, Sherman WB (2012) MP-29, a clonal interspecific hybrid for Peach. HortScience 47:128-131

Beckman TG, Pusey PL (2001) Field testing peach rootstocks for resistance to Armillaria root rot. HortScience 36:101-103

Devkota P, Hammerschmidt R (2019) A rapid and holistic approach to screen susceptibility of Prunus species to Armillaria root rot. Forest Pathol 49. https://doi.org/10.1111/efp.12547

Economou AS (2013) From microcutting to microplant establishment: key points to consider for maximum success in woody plants. Acta Hort 988:43-56

Elías-Román RD, Medel-Ortiz R, Alvarado-Rosales D, Hanna JW, RossDavis AL, Kim MS, Klopfenstein NB (2018) Armillaria mexicana a newly described species from Mexico. Mycologia 110:347-360

Foster A, Gifford E (1974) Morphology and evolution of angiosperms. In: Comparative morphology of vascular plants. WH Freeman and Company, San Francisco, pp 588-592

Hartman HT, Kester DE, Davies FT, Geneve RL, Wilson SB (2018) Plant propagation principles and practices, 9th edn. Prentice Hall Publishers, New York, p 698

Jacobsen AL, Pratt RB, Tobin MF, Hacke UG, Ewers FW (2012) A global analysis of xylem length in woody plants. Am J Bot 99: $1583-1591$
Kalinina A, Brown DCW (2007) Micropropagation of ornamental Prunus spp. and GF305 peach, a Prunus viral indicator. Plant Cell Rep 26:927-935

Kirdimanee C, Kitaya Y, Kozai T (1995) Effects of $\mathrm{CO}_{2}$-enrichment and supporting materials in vitro on photoautotrophic growth of Eucalyptus plantlets in vitro and ex vitro: anatomical comparisons. Acta Hortic 393:111-115

Koch RA, Wilson A, Sene O, Henkel TW, Aime MC (2017) Resolved phylogeny and biogeography of the root pathogen Armillaria and its gasteroid relative, Guyanagaster. BMC Evolution Biol 17:33

Kovalchuk IY, Mukhtidinova Z, Madiyeva G, Akin M, Eyduran E, Reed B (2018) Nitrogen ions and nitrogen ion proportions impact the growth of apricot (Prunus armeniaca) shoot cultures. Plant Cell Tiss Org Cult 133:263-273

Lloyd G, McCown B (1981) Commercially-feasible micropropagation of mountain laurel, Kalmia latifolia, by use of shoot-tip culture. Comb Proc Intl. Plant Prop Soc 30:421-427

Mansilla JP, Aguin O, Sainz MJ (2001) A fast method for production of Armillaria inoculum. Mycologia 93:612-615

Miller SB, Gasic K, Reighard GR, Henderson WG, Rollins PA, Vassalos M, Schnabel G (2020) Preventative root collar excavation reduces peach tree mortality caused by Armillaria root rot on replant sites. Plant Dis In press 104:1274-1279

Murashige T, Skoog F (1962) A revised medium for rapid growth and bio assays with tobacco tissue cultures. Physiol Plant 15(3):473-497

Newell C, Growns D, McComb J (2003) The influence of medium aeration on in vitro rooting of Australian plant microcuttings. Plant Cell Tiss Org Cult 55:133-139

Nicholson J, Shukla M, Saxena P (2020) In vitro rooting of hazelnuts (Corylus avellana $x$ Corylus americana) in a temporary immersion system. https://doi.org/10.1139/cjb-2019-0206

Quoirin M, Lepoivre P (1977) Improved media for in vitro culture of Prunus spp. Acta Hort 78:437-442

Raabe RD (1979) Testing grape rootstocks for resistance to the oak root fungus. Calif Plant Pathol 46:3-4

Raziq F, Fox RTV (2005) Combinations of fungal antagonists for biological control of Armillaria root rot of strawberry plants. Biol Agr Hort 23:45-57

Rizzo M, Porter K, Bassi D, Byrne D (1998) Growth of immature peach (Prunus persica [L.] Batsch) embryos on different media. Acta Hort 465:141-144

Sadeghi F, Yadollahi A, Jafarkhani-Kermani M, Eftekhari M (2015) Optimizing culture media for in vitro proliferation and rooting of Tetra (Prunus empyrean 3) rootstock. J Gen Eng Biotech 13:19-23

Savage EF, Hayden RA, Futral JG (1974) Effect of soil fumigants on growth, yield and longevity of Dixired peach trees. Res. Bull. 148, Department of Horticulture, University of Georgia, Griffin

Schnabel G, Rollins AP, Henderson GW (2011) Field evaluation of Trichoderma spp. for control of Armillaria root rot of peach. Online. Plant Health Progress. https://doi.org/10.1094/PHP-20111129-01-RS

Shaw CG, Kyle GA (1991) Armillaria root disease. In: USDA Agricultural Handbook No. 691. US Forest Service, Washington DC, pp 78-82

Sinclair JW, Byrne DH (2003) Improvement of peach embryo culture through manipulation of carbohydrate source and $\mathrm{pH}$. HortScience 38:582-585

Tombesi S, Johnson RS, Day KR, DeJong T (2010) Relationships between xylem vessel characteristics, calculated axial conductance and size controlling capacity of peach rootstocks. Ann Bot 105:327-331

Wilbur W, Munnecke DE, Darley EF (1972) Seasonal development of Armillaria root rot of peach as influenced by fungal isolates. Phytopathology 62:567-570 